\title{
Crystallization Behaviors Concerned with TTT and CCT Diagrams of Blast Furnace Slag Using Hot Thermocouple Technique
}

\author{
Yoshiaki KASHIWAYA, ${ }^{1)}$ Toshiki NAKAUCHI, ${ }^{2)}$ Khanh Son PHAM, ${ }^{3)}$ Seitarou AKIYAMA ${ }^{4)}$ \\ and Kuniyoshi ISHII
}

1) Graduate School of Engineering, Hokkaido University, Kita-ku, Kita 13-jo, Nishi 8-chome, Sapporo 060-8628 Japan.

2) Formerly Graduate School of Engineering, Hokkaido University. Now at Nippon Steel Co. Ltd., Kita-ku, Kita 13-jo, Nishi 8chome, Sapporo 060-8628 Japan. $\quad 3$ 3) Graduate School of Engineering, Hokkaido University, Kita-ku, Kita 13-jo, Nishi 8chome, Sapporo 060-8628 Japan. $\quad 4$ 4) Faculty of Engineering, Hokkaido University, Kita-ku, Kita 13-jo, Nishi 8-chome, Sapporo 060-8628 Japan. $\quad$ 5) Professor Emeritus, Hokkaido University. Now at Adviser of JFE Steel Co. LTD, Kawasakicho, Chuo-ku, Chiba 260-0835 Japan.

(Received on August 4, 2006; accepted on October 11, 2006)

\begin{abstract}
Currently, the most of slags are recycled and reused by taking the advantages of the feature of respective slags (e.g. the BF slag is used for cement and roadbed material, LD slag is also used for the roadbed material and marine resources, etc.). The quality and quantity of recycle of slags changed greatly within recent ten years and it will be expected as an important resource in the future. Whereas there is a remained possibility on the recycle of slags, most of slags have a high temperature more than $1500^{\circ} \mathrm{C}$, when it was exhausted.

In general, there are two cooling processes adopted into the slag treatment, one is an air-cooling process and the other is a water quenching process. However, those slag cooling processes does not utilize the sensible and the latent heat related to high temperature melt. If there were a TTT (Time-Temperature-Transformation: isothermal transformation) diagram and a CCT (Continuous-Cooling-Transformation: continuous cooling curve) diagram, the property of the final slag could be estimated by the designed cooling path. Furthermore, it could be possible or easier to recover the sensible and the latent heat through a given cooling path.

In the present study, using SHTT (Single Hot Thermocouple Technique), TTT and CCT diagrams of BF slags were measured. Crystallization behavior in the TTT and CCT diagrams of BF slag were clarified by XRD analysis, SEM observation and EDS analysis together with the in situ observation. Crystal phases in the TTT diagram for BF slag used were Gehlenite $\left(2 \mathrm{CaO} \cdot \mathrm{Al}_{2} \mathrm{O}_{3} \cdot \mathrm{SiO}_{2}\right)$ and Merwinite $\left(3 \mathrm{CaO} \cdot \mathrm{MgO} \cdot 2 \mathrm{SiO}_{2}\right)$. The Merwinite precipitated faster than the Gehlenite. The nose position of Merwinite was $4 \mathrm{~s}$ at $1090^{\circ} \mathrm{C}$ and the nose of Gehlenite was $8 \mathrm{~s}$ at $1230^{\circ} \mathrm{C}$. CCT diagram had wider glass region than TTT diagram and the temperature of crystal region decreased to $1340^{\circ} \mathrm{C}$ at $1000 \mathrm{~s}$ and $1160^{\circ} \mathrm{C}$ at $14 \mathrm{~s}$.
\end{abstract}

KEY WORDS: slag crystallization; blast furnace slag; TTT diagram; CCT diagram; hot thermocouple.

\section{Introduction}

Recently, aiming at the lower environmental load on the ironmaking and steelmaking, many researchers in the steel industries and institutions are studying for the decrease of energy consumption on the iron production. For instance, in accordance with the utilization of the green energy such as hydrogen and the recycle and reuse of an exhaust gas, the biomass and the waste plastic which can not be counted as the $\mathrm{CO}_{2}$ emission, the decrease of energy consumption is investigated energetically.

In such a circumstance, slags are generating about 38 million tons per year in the iron and steel industry in Japan (2004 by Nippon Slag Association). The slags are classified into the blast furnace (BF) slag, the converter (LD) slag, and the electric arc furnace (EAF) slag. The BF slag is about 25 million tons, the LD slag is about 9.5 million tons, and the EAF slag is about 3.5 million tons.

Currently, the most of slags are recycled and reused by taking the advantages of the feature of respective slags (e.g. the BF slag is used for cement and roadbed material, LD slag is also used for the roadbed material and marine resources, etc.). The quality and quantity of recycle of slags changed greatly within recent ten years and it will be expected as an important resource in the future. Whereas there is a remained possibility on the recycle of slags, most of slags have a high temperature more than $1500^{\circ} \mathrm{C}$, when it was exhausted.

In general, there are two cooling processes for the slag treatment, one is an air-cooling process and the other is a water quenching process. The air-cooling process is that a molten slag was cooled naturally in a cooling yard. The property of air-cooled slag is dense and hard and closed to a rock which includes a crystalline phase. The air-cooling 


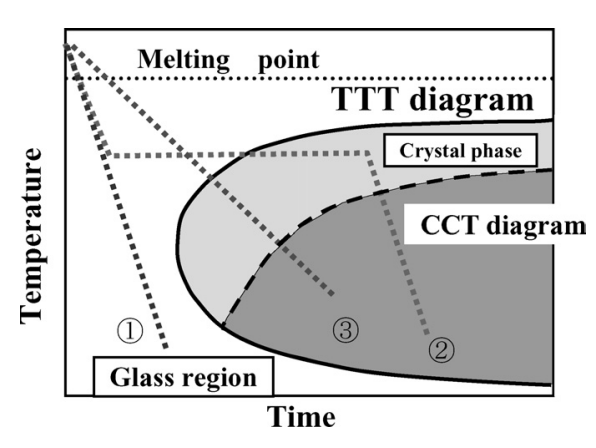

Fig. 1. Illustration of TTT and CCT diagrams.

processing is adopted on the all slags (the BF, LD and EAF slags). The water quenching process is mainly adopted into the processing of BF slag. The molten slag is quenched by pressurized water jet and simultaneously thrown into a water flow. The property of slag obtained is a glassy (amorphous) and a granulated one.

However, those slag cooling processes does not utilize the sensible and the latent heat related to high temperature melt when the slags are exhausted. Then, it is important to develop an ideal slag treatment process that is able to produce the value-added slags by not only the effective utilization of the sensible and the latent heat but also the positive control of microstructure of slag. For this purpose, the authors would like to emphasize the importance of TTT (Time-Temperature-Transformation: isothermal transformation) diagram and CCT (Continuous-Cooling-Transformation: continuous cooling curve) diagram.

Typical TTT and CCT diagrams ${ }^{1)}$ are illustrated in Fig. 1. When a slag was cooled along a given cooling path, a microstructure of slag could be expected. For example, the cooling path No. 1 in Fig. 1 will form a glassy slag. The cooling paths No. 2 and No. 3 which are passing in the TTT diagram or the CCT diagram will form the crystalline phases, however, the kind of crystal and its morphology will be different between the two paths. The obtained microstructure can be controlled through an adequate cooling path in accordance with the purpose of utilization of slag. Moreover, it would be easier to recover the heat of slag because the cooling path could be fixed in advance. ${ }^{2-4)}$ Through the existence of TTT and CCT diagrams, the promotion of slag recycle and reuse will be enhanced, since the physical and chemical properties are predictable. ${ }^{4,6-10)}$

In the present study,

(1) In situ observation of the crystallization of BF slag was carried out.

(2) In addition, XRD analysis for clarifying the crystal phase was carried out.

(3) Decisions of the beginning of crystallization of TTT and CCT diagrams were performed through the both results of (1) and (2).

(4) SEM observation and EDS analysis of slag sample quenched from several temperatures and times were carried out.

\section{Experimental}

\subsection{Hot Thermocouple Technique}

The melting and solidification experiments of slag sam-
Table 1. Chemical composition of BF slag and basicity.

\begin{tabular}{|l|l|l|l|l|l|l|l|}
\hline & $\mathrm{CaO}$ & $\mathrm{SiO}_{2}$ & $\mathrm{Al}_{2} \mathrm{O}_{3}$ & $\mathrm{MgO}$ & $\mathrm{Fe}_{2} \mathrm{O}_{3}$ & $\mathrm{MnO}$ & $\mathrm{C} / \mathrm{S}$ \\
\hline BF slag & 42.99 & 33.52 & 13.77 & 6.28 & $<0.37$ & 0.27 & 1.28 \\
\hline
\end{tabular}

ple were carried out using Hot Thermocouple Technique (HTT). Generally, a solidification phenomenon was studied using DTA (differential thermal analysis), ${ }^{5)}$ however, it was difficult to observe the phenomenon directly and to apply the rapid quenching condition because the heating was done by an electric furnace having relatively large thermal inertia. On the other hand, in the case of HTT, as the sample can be melted on the thermocouple directly, the sensitivity is quite high and the rapid quenching experiment can be performed. The authors have performed the various kinds of experiment on the slag melting and solidification owing to these features of HT system. ${ }^{6-8)}$

The details of the principle of HTT have mentioned in the previous paper. ${ }^{6,7)}$ Here, a brief explanation is presented. In HTT, $50 \mathrm{~Hz}$ or $60 \mathrm{~Hz}$ electric current is directly applied to a thermocouple and the heating is attained by the Joule effect, when the electric wave is rectified into a halfwave by SCR (Silicon Controlled Rectifier). Then, it can be utilized the non-heating period as a temperature measurement one.

There are two kinds of HTT. One is the Single Hot Thermocouple Technique (SHTT) and the other is the Double Hot Thermocouple Technique (DHTT). ${ }^{6}$ ) The DHTT is the technique that a sample is melted between two thermocouples, which can design the temperature gradient. DHTT enables to observe the crystallization under the specific temperature condition of a transparent or a translucent slag and the Marangoni convection of molten slag and so on. In present study, the SHTT was used owing to its advantage that the sample could be melted on the hot thermocouple easily and set in front of the CCD camera.

In the present experiment, after the in situ measurement of TTT and CCT diagrams, to clarify the difference of crystal phases precipitated, SEM observation and EDS and XRD analyses were performed.

\subsection{Sample}

Sample of BF slag used in the present study was supplied by a steel maker. The chemical composition of the slag was shown in Table 1. The basicities $\left(\mathrm{C} / \mathrm{S}=\mathrm{CaO} / \mathrm{SiO}_{2}\right)$ of $\mathrm{BF}$ slag is 1.28 .

\subsection{Experimental Apparatus}

Figure 2 illustrates the experimental apparatus having hot thermocouple driver and in situ observation system. The setup was newly developed on the basis of the one made by Kashiwaya et l. $^{6)}$ in Carnegie Mellon University, in which the air cooling device was installed, that is activated by a computer signal synchronized with the turn-off of the electric power of furnace and hot thermocouple. A compressed air (1 atm and ambient temperature) blew on the sample via electromagnetic valve which was controlled by computer.

It was found by the preliminary experiment that the nose positions of TTT diagrams for the BF slag were around $3 \mathrm{~s}$ to $5 \mathrm{~s}$, which was faster than the Mold slag. It was neces- 


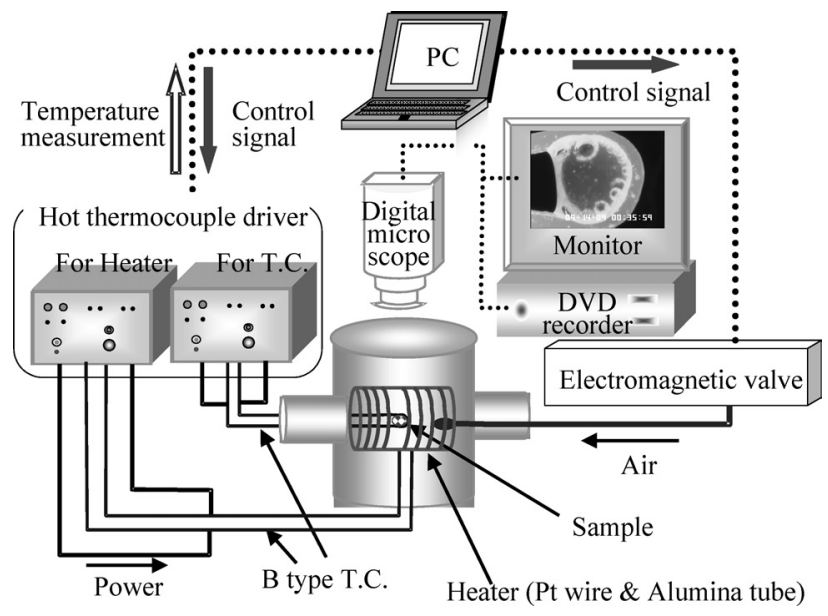

Fig. 2. Schematics of experimental apparatus.

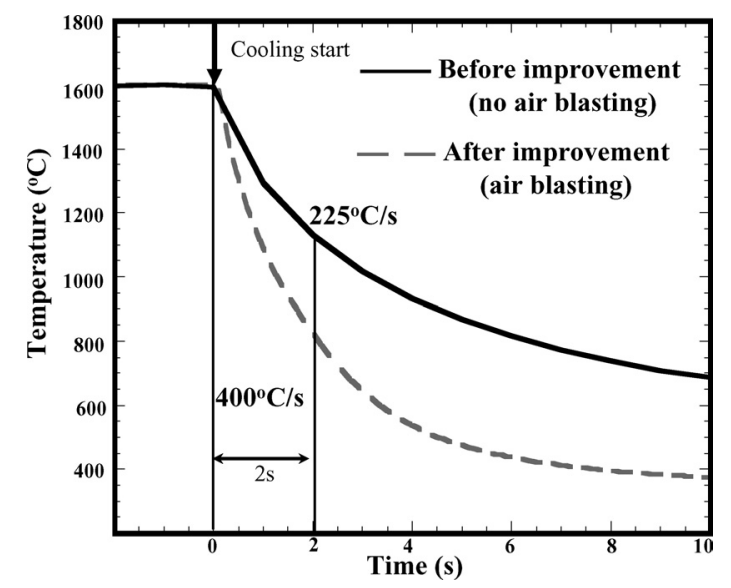

Fig. 3. The increase of cooling rate by improvement of apparatus.

sary to quench the sample at least $300^{\circ} \mathrm{C} / \mathrm{s}$ for getting the glass phase. Before the modification of the present experimental apparatus, the maximum quenching rate was $225^{\circ} \mathrm{C} / \mathrm{s}$ (In Fig. 3, the cooling curve (solid line) was obtained only by the turning off the electric power of hot thermocouple and furnace). The improvement was performed as mentioned above and the obtained cooling rate was $400^{\circ} \mathrm{C} / \mathrm{s}$ (Fig. 3, broken line), which was sufficiently high for getting a glassy state of BF slag.

The solidification behavior of sample during experiment was observed by a digital microscope and recorded on DVD equipment. The thermocouple was B-type $(0.5 \mathrm{~mm} \phi$, $\mathrm{Pt}-30 \% \mathrm{Rh}, 6 \% \mathrm{Rh})$ and the shape of tip for melting the sample was adjusted to a given configuration using a die made of stainless (the inner width of tip of thermocouple was $2 \mathrm{~mm}$ ).

\section{Results and Discussions}

\subsection{Measurement of TTT Diagrams}

3.1.1. Tentative TTT Diagram Obtained by in Situ Observation

If the crystal precipitated during solidification was opaque and optically constant, the time of the beginning of crystallization could be determined easily. However, it was found that some of slag would precipitate a transparent or a

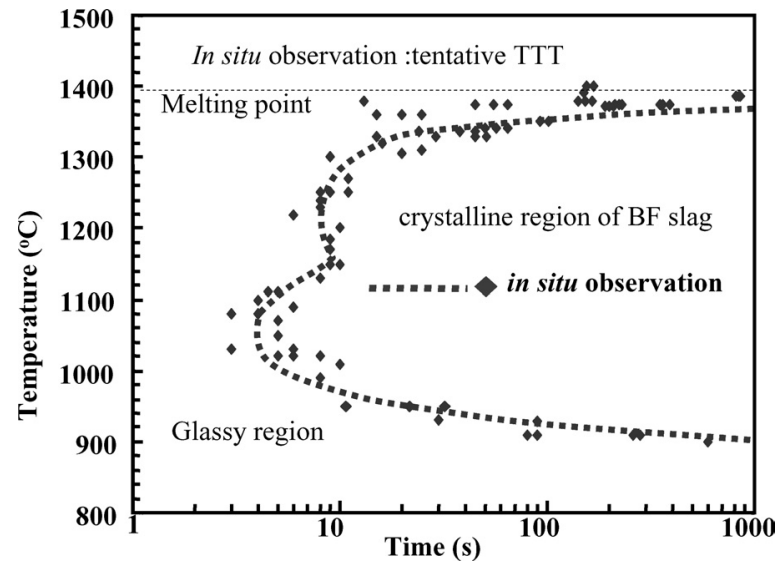

Fig. 4. TTT diagram of the beginning of crystallization obtained by in situ observation of BF slag (tentative diagram).

translucent crystal which was difficult to decide the time of beginning of crystallization. At first, the easier method (in situ observation) for determining the beginning of crystallization was performed. Then, the XRD analysis was carried for compensating the defect of the in situ method in later Sec. 3.1.2.

The TTT diagram of the beginning of crystallization was obtained from the following procedures; (1) Using SHTT, a sample was melted quickly over $1500^{\circ} \mathrm{C}$. It is preferable to increase the temperature as rapid as possible, because there is some possibility to precipitate a phase having high melting point such as a dicalcium silicate $\left(2 \mathrm{CaO} \cdot \mathrm{SiO}_{2}\right)$. While the extremely high heating up rate would increase a risk to melt down the thermocouple itself, it would be important to get an empirical limitation for a rapid heating up. (2) Temperature of the melted sample was to be stable at $1600^{\circ} \mathrm{C}$, which was the staring temperature. (3) The sample was quenched to a given temperature and the time of a beginning of crystallization was measured. (4) The starting times at different temperatures were measured through the procedures from (1) to (3). (5) TTT diagram was obtained by the plotting of the times vs. temperatures.

Figure 4 shows the tentative TTT diagram of the BF slag obtained. The horizontal axis is the time in a natural logarithm and the vertical one is the temperature that a crystal precipitated.

The nose position of BF slag was about $9 \mathrm{~s}$ at $1250^{\circ} \mathrm{C}$ and was $4 \mathrm{~s}$ at $1050^{\circ} \mathrm{C}$, which meant the double nose TTT diagram. In addition, the melting point of $\mathrm{BF}$ slag was about $1400^{\circ} \mathrm{C}$. Generally, the double nose TTT diagram will have more than two kinds of crystals. In the case of BF slag, there is no information about the kind of crystal phase, only TTT diagram having a close chemical composition of BF slag was published by $\mathrm{P}$. Rocabois et al. ${ }^{13)}$ in which several crystal phases were reported such as pseudowollastonite (CS: $\left.\mathrm{CaO} \cdot \mathrm{SiO}_{2}\right)$, anorthite $\left(\mathrm{CAS}_{2}: \mathrm{CaO}\right.$. $\left.\mathrm{Al}_{2} \mathrm{O}_{3} \cdot 2 \mathrm{SiO}_{2}\right)$, Gehlenite $\left(\mathrm{C}_{2} \mathrm{AS}: 2 \mathrm{CaO} \cdot \mathrm{Al}_{2} \mathrm{O}_{3} \cdot \mathrm{SiO}_{2}\right)$ and Akermanite $\left(\mathrm{C}_{2} \mathrm{MS}_{2}: 2 \mathrm{CaO} \cdot \mathrm{MgO} \cdot 2 \mathrm{SiO}_{2}\right)$, but there is a little information about optical characteristics during precipitation, which is related to the result of in situ observation. As shown in Fig. 4, there are relatively large scattering of the data. The causes on the results will come from the followings factor;

(1) Many impurities in the BF slag will affect the behav- 
ior of the crystallization. Especially, the beginning of crystal precipitation will be changed by the impurities such as $\mathrm{Fe}_{2} \mathrm{O}_{3}, \mathrm{FeO}, \mathrm{MnO}, \mathrm{P}_{2} \mathrm{O}_{5}, \mathrm{~S}, \mathrm{Na}_{2} \mathrm{O}, \mathrm{K}_{2} \mathrm{O}$, and so on.

(2) The content of $\mathrm{H}_{2} \mathrm{O}$ will enhance the crystallization behavior. ${ }^{9)}$

(3) Tthe optical property will be important factor for the visible crystal.

(4) The size of crystal is also important, and the small size at the beginning of crystallization can not see, depending on the resolution of the optical system. The distinct definition of the beginning of the crystallization will be necessary to deduce with a theoretical procedure. $^{6,7)}$

\subsubsection{Determination of Crystal Phases and TTT Diagram by XRD}

XRD analysis was performed to determine the crystal phases in the obtained TTT diagram of BF slag. The holding temperatures were decided to the one at two noses $\left(1300^{\circ} \mathrm{C}, 1050^{\circ} \mathrm{C}\right.$ or $\left.1000^{\circ} \mathrm{C}\right)$ and at the middle of the temperatures $\left(1170^{\circ} \mathrm{C}\right)$ based on the Fig. 4 . At first, the holding times were $30 \mathrm{~s}, 100 \mathrm{~s}$ and $1000 \mathrm{~s}$ at those three temperatures $\left(1300^{\circ} \mathrm{C}, 1170^{\circ} \mathrm{C}\right.$ or $\left.1000^{\circ} \mathrm{C}\right)$.

Since the amount of sample was about $10 \mathrm{mg}$ which was very small for conventional XRD method, the conditions of $\mathrm{XRD}$ were selected as large as possible $(30 \mathrm{kv}, 300 \mathrm{~mA}, \mathrm{Cu}-$ $\mathrm{K} \alpha$ ), and the measuring time was $320 \mathrm{~min}$ for one sample $\left(2 \theta=10^{\circ}-90^{\circ}, 0.25^{\circ} / \mathrm{min}\right)$. In addition, the small sample was crushed in a small mortar, then the obtained powder was gathered at the area $(5 \mathrm{~mm} \times 10 \mathrm{~mm})$ on the slid glass with small amount of glue, where the X-ray irradiation was focused. From this method, the crystal phases in the sample obtained from HTT were determined with relatively high accuracy.

Figure 5 shows the typical example of XRD of the BF slag quenched from $1300^{\circ} \mathrm{C}$ at $1000 \mathrm{~s}$, in which the crystallization seemed to complete. The obtained peaks were complicated. From the composition of sample, Merwinite (ASTM35-591; $\mathrm{C}_{3} \mathrm{MS}_{2}$. $3 \mathrm{CaO} \cdot \mathrm{MgO} \cdot 2 \mathrm{SiO}_{2}$ ), Gehlenite (ASTM9-216: $\mathrm{C}_{2} \mathrm{AS}, 2 \mathrm{CaO} \cdot \mathrm{Al}_{2} \mathrm{O}_{3} \cdot \mathrm{SiO}_{2}$ ) and Akermanite (ASTM4-681: $\mathrm{C}_{2} \mathrm{MS}_{2}: 2 \mathrm{CaO} \cdot \mathrm{MgO} \cdot 2 \mathrm{SiO}_{2}$ ) are possible to exist in this system. Moreover, the peaks of Gehlenite and Akermanite makes a solid solution called as Melilite and are quite resemble as shown by reference data in Fig. 5. However, if the profiles were magnified in the region near the main peak from $30^{\circ}$ to $35^{\circ}$, it could be easily deter-

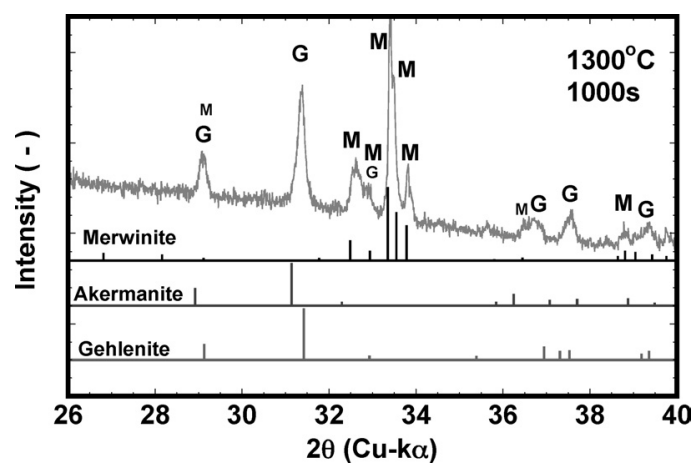

Fig. 5. Determination of crystal phases precipitated in BF slag quenched from $1300^{\circ} \mathrm{C}$ at $1000 \mathrm{~s}$. mined through the comparison with the reference data. Although the main peaks of Gehlenite $\left(31.360^{\circ}\right)$ and Akermanite $\left(31.163^{\circ}\right)$ were close, the crystal phase precipitated in the BF slag was determined as Gehlenite. Furthermore, the peaks $\left(33.351^{\circ}\left(I / I_{\mathrm{o}}=100\right), 33.548^{\circ}\left(I / I_{\mathrm{o}}=65\right), 33.785^{\circ}\right.$ $\left.\left(I / I_{\mathrm{o}}=47\right)\right)$ belonging in the Merwinite are overlapped into two peaks. These precise analyses enabled to distinguish those three crystal phases. Finally, it was concluded that Merwinite and Gehlenite were precipitated in the BF slag system having the composition shown in Table 1. On the other hand, the Gibbs free energy of formation of these compounds were calculated and shown in Appendix (Fig. A1). ${ }^{14)}$ It is found that the free energy of Merwinite is lowest among three compounds and the order of the stable compound is Merwinite, Gehlenite and Akermanite.

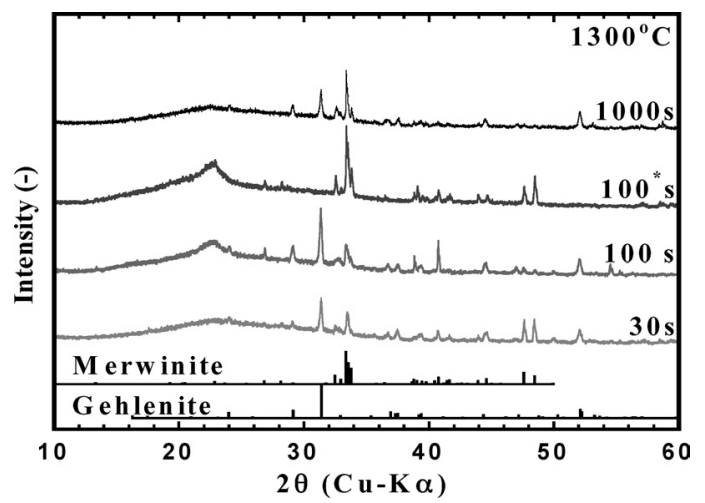

Fig. 6. Comparison of X-ray diffraction patterns of BF slag at $1300^{\circ} \mathrm{C}$.

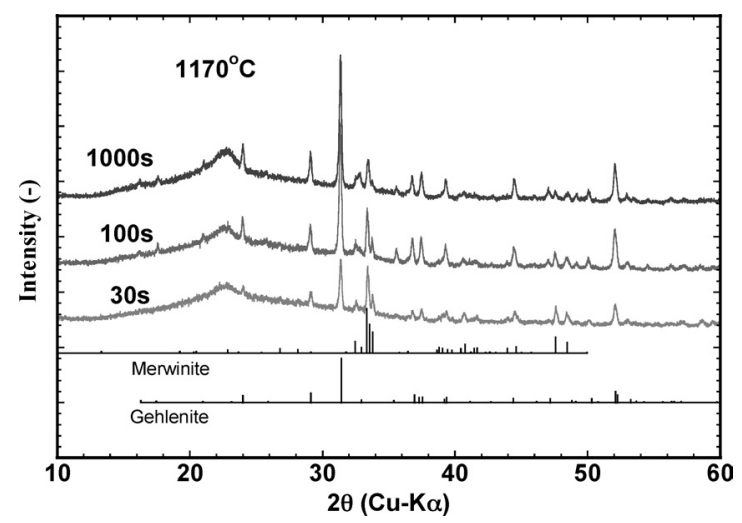

Fig. 7. Comparison of X-ray diffraction patterns of BF slag at $1170^{\circ} \mathrm{C}$.

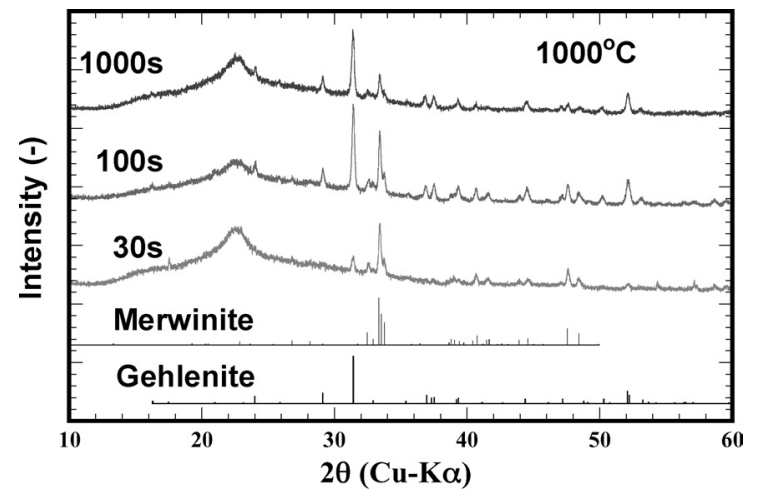

Fig. 8. Comparison of X-ray diffraction patterns of BF slag at $1000^{\circ} \mathrm{C}$. 
Figures 6-8 show the results of XRD analysis of samples quenched from three different temperatures, $1300^{\circ} \mathrm{C}$, $1170^{\circ} \mathrm{C}$ and $1000^{\circ} \mathrm{C}$, respectively. Figure 6 shows the XRD patterns of samples held at $1300^{\circ} \mathrm{C}$ for $30 \mathrm{~s}, 100 \mathrm{~s}$ and $1000 \mathrm{~s}$. The broad peak located around $2 \theta=23^{\circ}\left(15^{\circ}-35^{\circ}\right)$ comes from the slid glass used as a sample holder, and the broad peak does not express the glassy state of sample. At $1300^{\circ} \mathrm{C}$, the crystal phases were Merwinite and Gehlenite. Those peaks were not so intense in comparison with the lower temperature as shown later (Figs. 7 and 8). The state of Merwinite and Gehlenite at this temperature was not so stable, because the temperature was closed to the melting point. Furthermore, as the data scattering was relatively large, only Merwinite was irregularly observed at $100 \mathrm{~s}$ as shown in Fig. 6. The cause will related to the difference of diffusion coefficient between $\mathrm{Mg}$ and $\mathrm{Al}$ in the melt which are discussed later.

The results of XRD of the samples quenched from $1170^{\circ} \mathrm{C}$ for different holding times $(30 \mathrm{~s}, 100 \mathrm{~s}, 1000 \mathrm{~s})$ were shown in Fig. 7. Although both the Merwinite and the Gehlenite existed at $1170^{\circ} \mathrm{C}$, the amount of Gehlenite increased with increasing holding time. This tendency was the same as the results at $1000^{\circ} \mathrm{C}$ as shown in Fig. 8 .

The optical microscope was used to examine the crystal characteristics at the beginning of crystallization, which could confirm the result of in situ observation (Fig. 4). In Fig. 9, the obtained crystal images were somewhat opaque $\left(1300^{\circ} \mathrm{C}, 30 \mathrm{~s}\right.$, Fig. $\left.9(\mathrm{a})\right)$ and lately translucent $\left(1300^{\circ} \mathrm{C}\right.$, $100 \mathrm{~s}$, Fig. 9(b)). It was quite irregular crystallization observed both in the in situ observation and the optical microscope. In the case of $100 \mathrm{~s}$ at $1300^{\circ} \mathrm{C}$, only Merwinite was sometime observed (Fig. 6), while both Gehlenite and Merwinite were usually precipitated. Generally, the opaque crystal was Gehlenite+Merwinite (Fig. 9(a)) and the translucent one was Merwinite as shown in Fig. 9(b). These results suggested that the formation-decomposition process of the Merwinite and the Gehlenite might exist in the BF slag in the course of crystallization at this temperature range $\left(1300^{\circ} \mathrm{C}\right)$. Nagasawa et al. ${ }^{15-17)}$ reported the change of diffusion coefficient of $\mathrm{Mg}$ in Akermanite-Gehlenite system. The self-diffusion coefficient of $\mathrm{Mg}$ in Akermanite was a half order of magnitude larger than that in Gehlenite

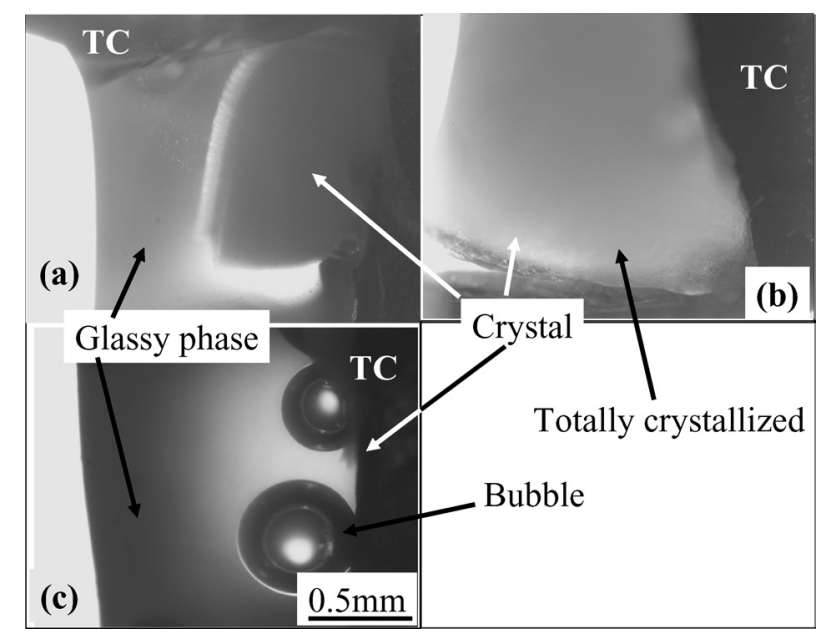

Fig. 9. Optical characteristics of the quenched slag and the differences of crystals precipitate. (a) $1300^{\circ} \mathrm{C}, 30 \mathrm{~s}$, (b) $1300^{\circ} \mathrm{C}, 100 \mathrm{~s},(\mathrm{c}) 1170^{\circ} \mathrm{C}, 6 \mathrm{~s}$. and $70 \mathrm{~mol} \%$ Akermanite $-30 \mathrm{~mol} \%$ Gehlenite. Moreover, the diffusion coefficient changed with the composition of Akermanite-Gehlenite. This effect might work in the Merwinite-Gehlenite system. Although the diffusions of $\mathrm{Mg}$ and $\mathrm{Al}$ in an undercooled liquid in this study would be different from the result of Nagasawa et al., the difference of diffusion coefficient of cations $(\mathrm{Mg}, \mathrm{Al}, \mathrm{Ca}$ and $\mathrm{Si}$ ) would be affect to the behavior of the formation and decomposition of both the crystals at the beginning of crystallization. The details of the crystallization taking into account of the difference of the diffusion coefficient of the respective species would be an important subject to be clarified.

It is difficult to determine the exact time of the beginning of crystallization by the in situ observation. Kashiwaya et $a l .{ }^{6,7)}$ was estimate the time by the kinetic method applying the Johnson-Mehl-Avrami equation. However, in this study, it was difficult to observe the crystal growth directly, because the optical nature of the crystal was a transparent or a translucent. Then, many samples were quenched from several conditions and the beginning of crystallization was determined by optical microscope and XRD analysis. In Fig. 9(c), there was very small crystal on the surface of thermocouple adjacent to the bubble, which might be difficult to recognize in high temperature. Although the points of $1170^{\circ} \mathrm{C}$ at $6 \mathrm{~s}$ in the tentative TTT diagram were in the region of the glassy, it could be concluded that this region was in the crystal phase.

Figures 10 to 12 are the results of XRD for determining the crystal phase in the initial stage of crystallization at $1300^{\circ} \mathrm{C}, 1170^{\circ} \mathrm{C}$ and $1050^{\circ} \mathrm{C}$, respectively. In the case of $1300^{\circ} \mathrm{C}$ (Fig. 10), crystal phases, which were Gehlenite and

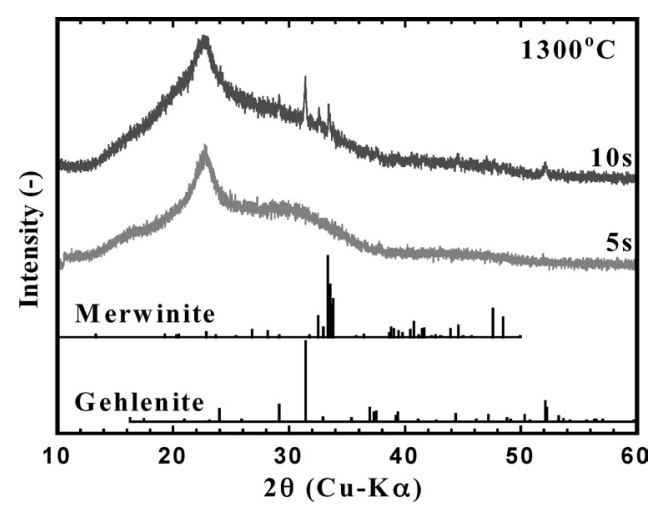

Fig. 10. XRD profiles of BF slag quenched from $5 \mathrm{~s}$ and $10 \mathrm{~s}$ at $1300^{\circ} \mathrm{C}$.

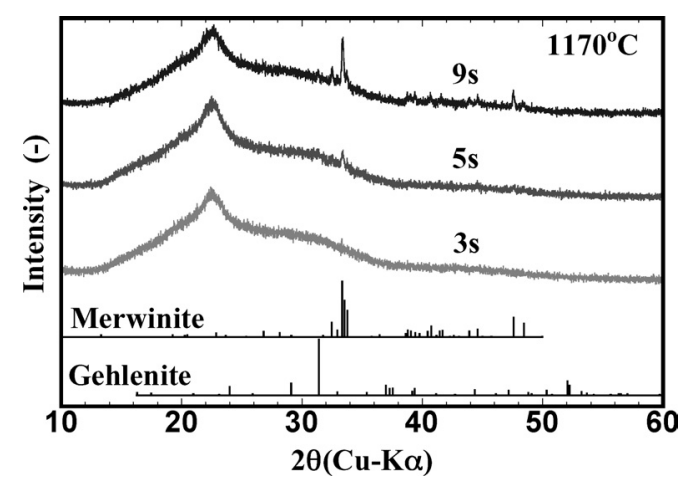

Fig. 11. XRD profiles of BF slag quenched from $3 \mathrm{~s}, 5 \mathrm{~s}$ and $9 \mathrm{~s}$ at $1170^{\circ} \mathrm{C}$. 
Merwinite, appeared at $10 \mathrm{~s}$. Since the result at $5 \mathrm{~s}$ did not show the crystal phase, it was considered that the beginning of crystallization was around $10 \mathrm{~s}$.

Merwinite was dominant both in $1170^{\circ} \mathrm{C}$ (Fig. 11) and $1050^{\circ} \mathrm{C}$ (Fig. 12) at the initial stage of crystallization, and the beginning of crystallization was about $4 \mathrm{~s}$ at $1170^{\circ} \mathrm{C}$ and $4 \mathrm{~s}$ at $1050^{\circ} \mathrm{C}$.

Finally, the TTT diagram of BF slag was determined as shown in Fig. 13. The upper nose in the tentative TTT diagram obtained by the in situ observation would be the nose of Gehlenite which located inside the TTT diagram of Merwinite. The crystal of Merwinite precipitated in high temperature was a transparent or a translucent which was difficult to see in high temperature. The nose position of Merwinite located around $4 \mathrm{~s}$ at $1090^{\circ} \mathrm{C}$. The reason why the Merwinite precipitates faster than the Gehlenite will be resulted from the lower free energy (Fig. A1), however, the behavior of crystallization until a stable state $(100 \%$ of crystallization degree) will be affected by the difference of the diffusibility of cations that construct the Merwinite and the Gehlenite. Especially, as $\mathrm{Ca}$ and $\mathrm{Si}$ are common elements in the both compounds, the difference of the dif-

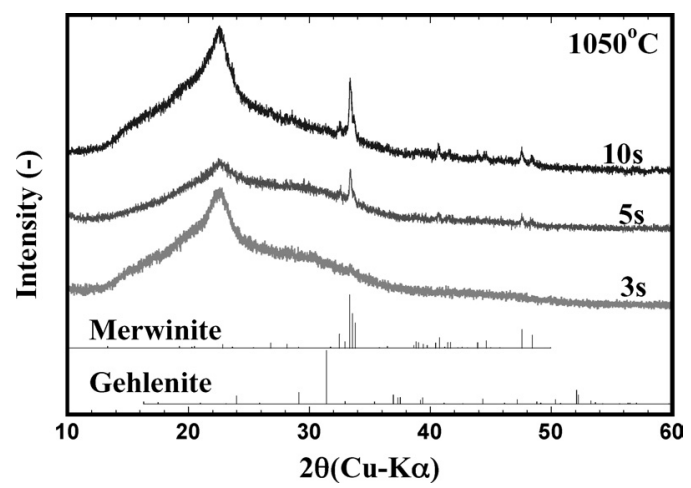

Fig. 12. XRD profiles of BF slag quenched from $3 \mathrm{~s}, 5 \mathrm{~s}$ and $10 \mathrm{~s}$ at $1050^{\circ} \mathrm{C}$.

fusibility of $\mathrm{Mg}$ and $\mathrm{Al}$ will be important to clarify the crystallization behavior around $1300^{\circ} \mathrm{C}$.

Figure 14 is the pseudobinary phase diagram of Merwinite-Gehlenite system. ${ }^{11)}$ The composition in the present

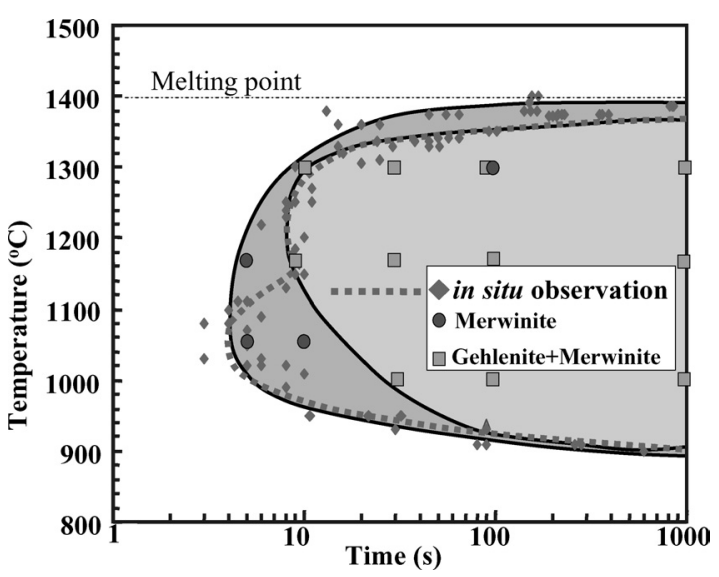

Fig. 13. TTT diagrams of the beginning of crystallization obtained by in situ and ex situ observations by optical microscope and XRD analysis.

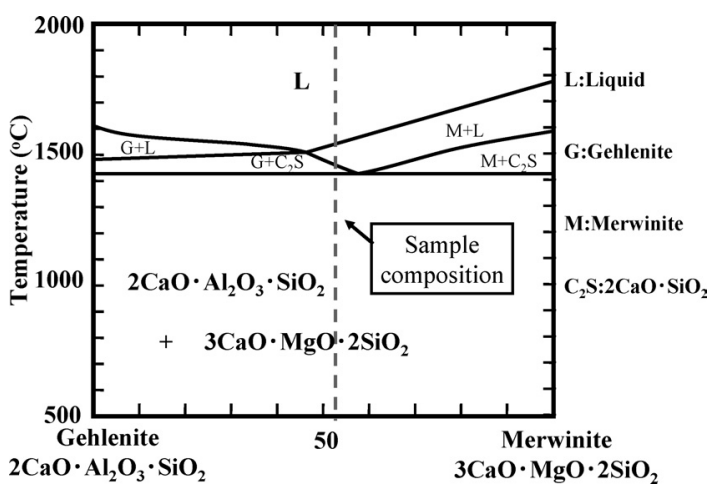

Fig. 14. Pseudobinary phase diagram of Merwinite-Gehlenite system. ${ }^{11)}$

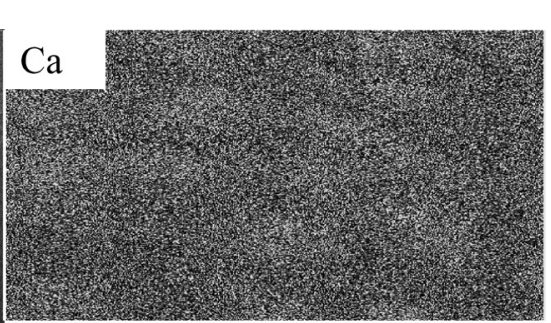

$\mathrm{Mg}$
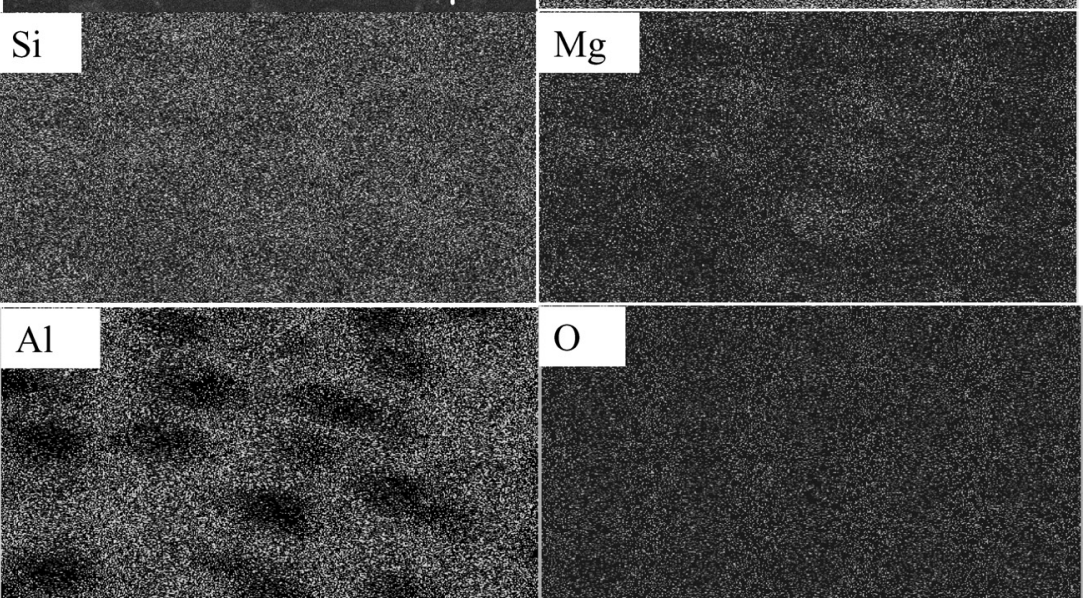

Fig. 15. SEM image and EDS mapping of BF slag holding at $1300^{\circ} \mathrm{C}$ for $1000 \mathrm{~s}$ (M: Merwinite, G: Gehlenite). 


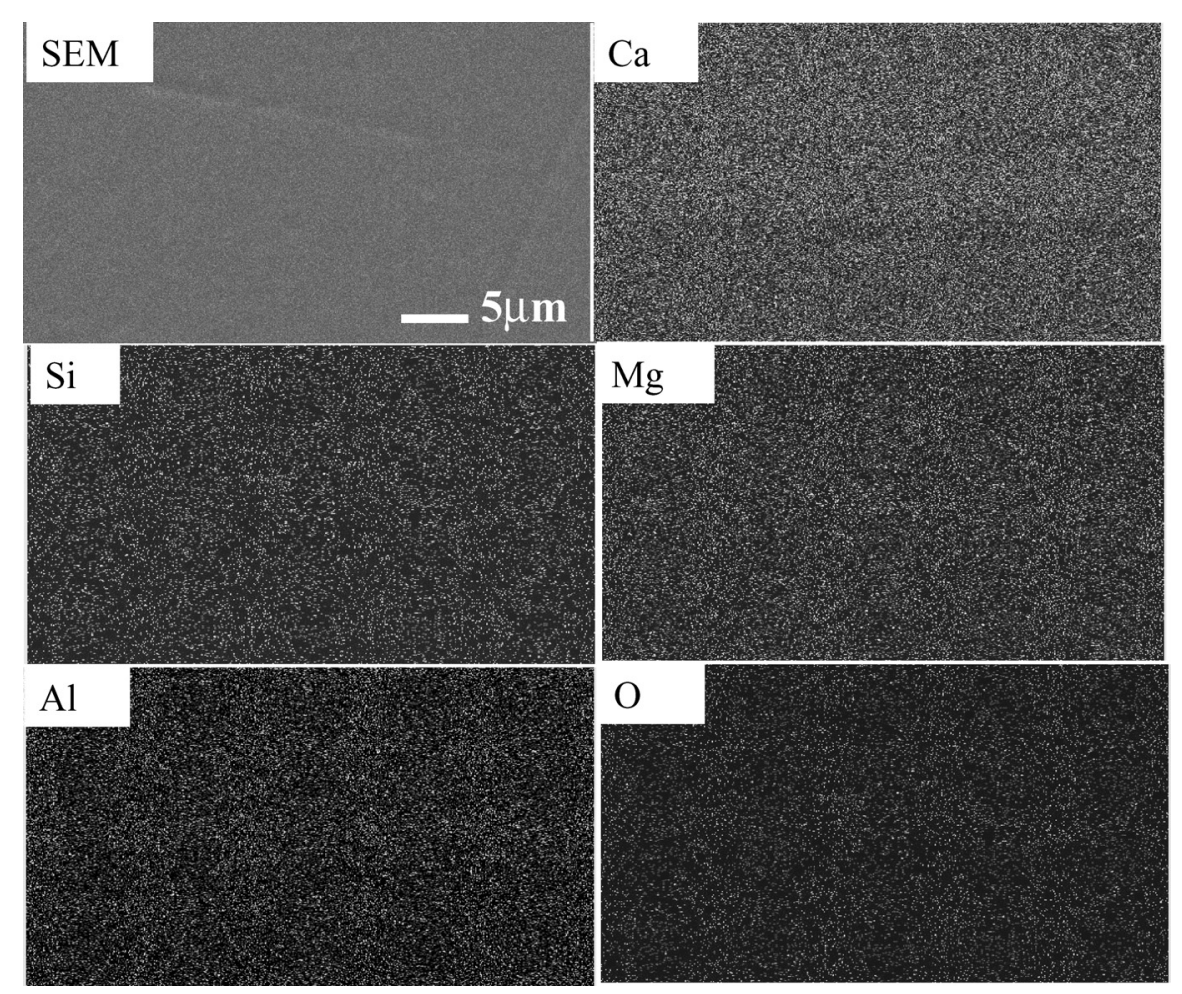

Fig. 16. SEM image and EDS mappings of BF slag holding at $1170^{\circ} \mathrm{C}, 1000 \mathrm{~s}$.

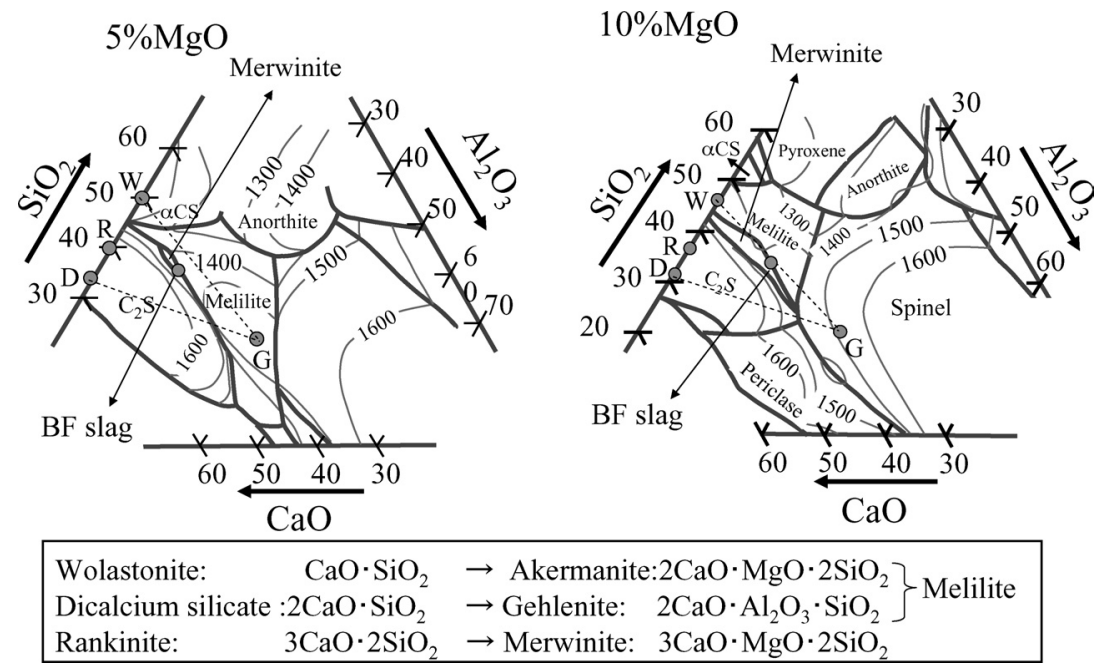

Fig. 17. Pseudo-ternary phase diagrams of $\mathrm{CaO}-\mathrm{SiO}_{2}-\mathrm{Al}_{2} \mathrm{O}_{3}$ system at $5 \%$ and $10 \% \mathrm{MgO}$.

BF slag is in about $53 \%$ Merwinite. The initial phase precipitated is Merwinite in the composition. In addition, if the composition of slag was ununiformed, there might be a possibility of the precipitation of Gehlenite as primary crystal.

Figures 15 and 16 shows the results of SEM observation and EDS analysis of the samples quenched from $1300^{\circ} \mathrm{C}$ at $1000 \mathrm{~s}$ and $1170^{\circ} \mathrm{C}$ at $1000 \mathrm{~s}$, respectively. In Fig. 15, it was found that the primary crystal was Merwinite, which was concluded by the crystal area was low $\mathrm{Al}$ and high $\mathrm{Mg}$ contents. While the crystal image in the matrix was not obtained because of smaller crystal $(<1 \mu \mathrm{m})$, the matrix would be the solid solution of Merwinite and Gehlenite which was confirmed by the phase diagram (Fig. 14).

The crystal size grown at $1170^{\circ} \mathrm{C}$ shown in Fig. 16 was very small and less than the limit of resolution $(\fallingdotseq 1 \mu \mathrm{m})$ of SEM used. Almost uniform distribution of each elements was obtained.

The pseudo-ternary phase diagrams of $\mathrm{CaO}-\mathrm{SiO}_{2}-\mathrm{Al}_{2} \mathrm{O}_{3}$ system at $5 \%$ and $10 \% \mathrm{MgO}$ are shown in Fig. 17, ${ }^{11,12}$ ) where $\mathrm{W}, \mathrm{R}$ and $\mathrm{D}$ mean wolastonite $\left(\mathrm{CaO} \cdot \mathrm{SiO}_{2}\right)$, Rankinite $\left(3 \mathrm{CaO} \cdot 2 \mathrm{SiO}_{2}\right)$ and Dicalcium silicate $\left(2 \mathrm{CaO} \cdot \mathrm{SiO}_{2}\right)$, respectively. The composition of $\mathrm{BF}$ slag used was in the border between the regions of Merwinite and Melilite. The Melilite is a solid solution between Gehlenite $(2 \mathrm{CaO}$. $\left.\mathrm{Al}_{2} \mathrm{O}_{3} \cdot \mathrm{SiO}_{2}\right)$ and Akermanite $\left(2 \mathrm{CaO} \cdot \mathrm{MgO} \cdot 2 \mathrm{SiO}_{2}\right)$. From the $\mathrm{XRD}$, Akermanite was not found or was very small to be detected. The region of Merwinite quickly decreases with the decrease of $\mathrm{MgO}$ from $10 \%$ to $5 \%$, which means that according to the decrease of $\mathrm{MgO}$ with the precipitation of Merwinite, Melilite (Gehlenite) region increases. The average composition of sample was in the composition triangle WDG and was moved toward the line RG when the 


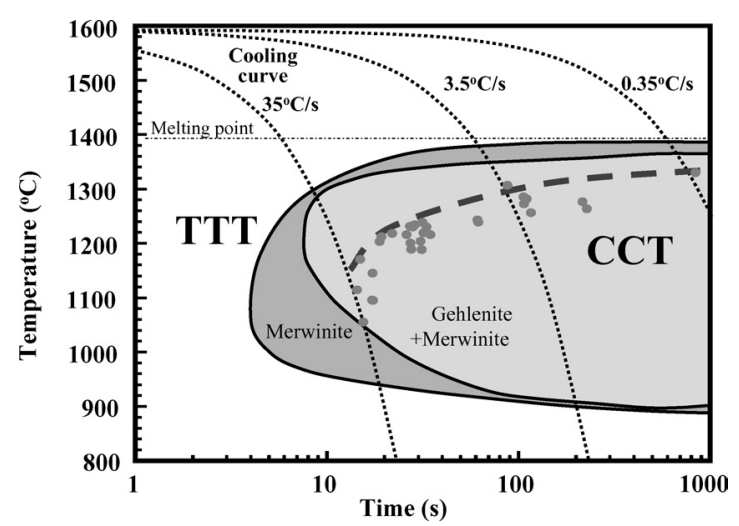

Fig. 18. The obtained CCT diagram of BF slag in comparison with the obtained TTT diagram.
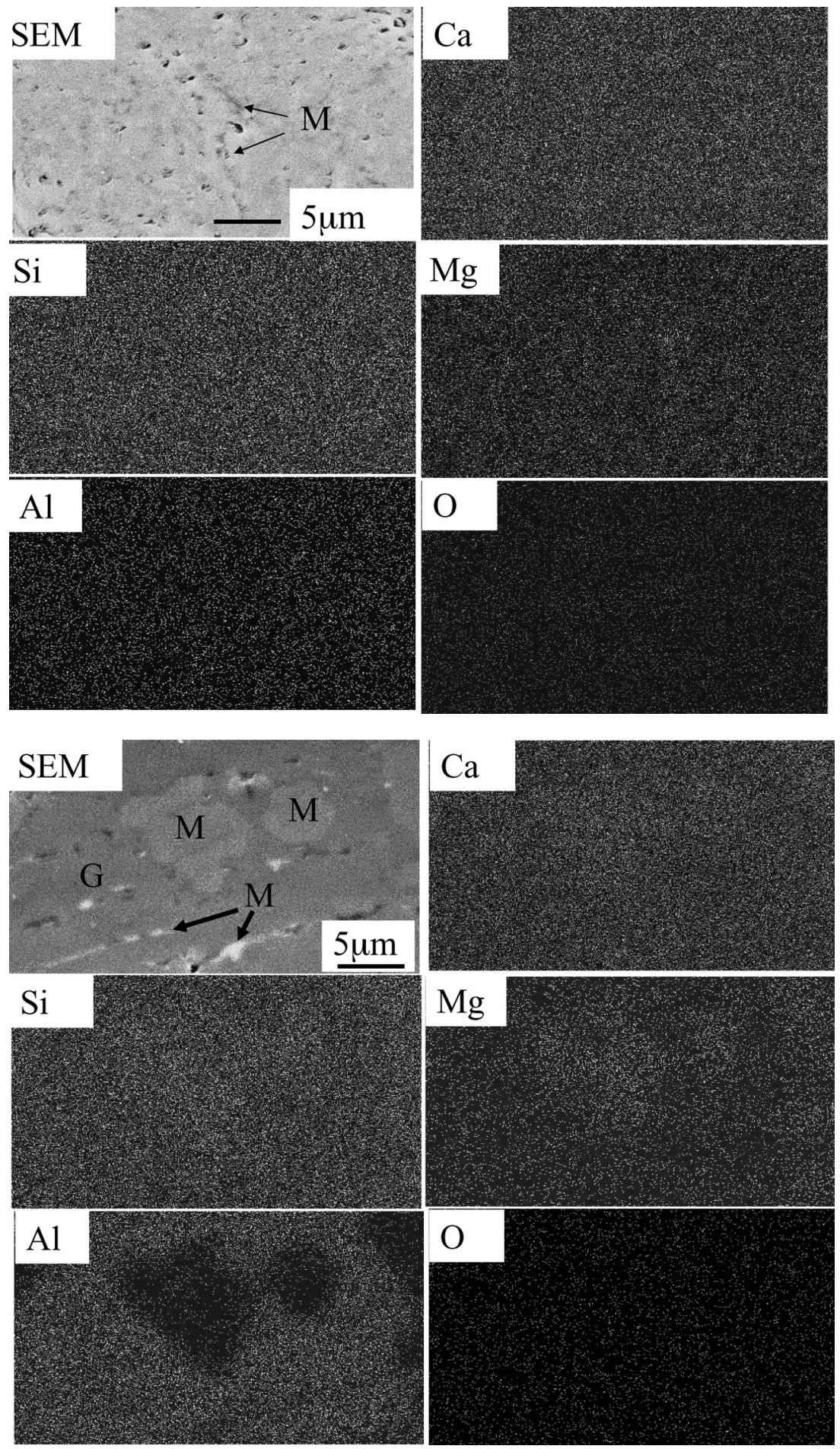

$\mathrm{MgO}$ decreased with solidification (point $\mathrm{R}$ is related to Merwinite).

\subsection{CCT Diagram by in Situ Observation}

CCT diagram of BF slag was measured by various cooling rate from $70^{\circ} \mathrm{C} / \mathrm{s}$ to $0.3^{\circ} \mathrm{C} / \mathrm{s}$ (typical cooling curves of $35^{\circ} \mathrm{C} / \mathrm{s}, 3.5^{\circ} \mathrm{C} / \mathrm{s}$ and $0.35 \mathrm{C} / \mathrm{s}$ were shown by the broken lines in Fig. 18). The temperatures of the beginning of crystallization on the cooling curves were plotted on the TTT diagram obtained. In the CCT diagram, glass region became large and the minimum temperature of crystallization decreased to $1160^{\circ} \mathrm{C}$ at $14 \mathrm{~s}$ and the maximum one was $1340^{\circ} \mathrm{C}$ at $1000 \mathrm{~s}$, which were general tendency of CCT
Fig. 19. SEM image and EDS mapping of BF slag cooled at $3.5^{\circ} \mathrm{C} / \mathrm{s}$ from 1600 to $600^{\circ} \mathrm{C}$.

Fig. 20. SEM image and EDS mapping of BF slag cooled at $0.35^{\circ} \mathrm{C} / \mathrm{min}$ from 1600 to $600^{\circ} \mathrm{C}$. 
v.s. TTT.

Figures 19 and 20 show the results of SEM observation and EDS analyses for the samples cooled from 1600 to $600^{\circ} \mathrm{C}$ with the cooling rates of $3.5^{\circ} \mathrm{C} / \mathrm{s}$ and $0.35^{\circ} \mathrm{C} / \mathrm{s}$, respectively. The microstructure of the sample with higher cooling rate of $3.5^{\circ} \mathrm{C} / \mathrm{s}$ in Fig. 19 showed a smaller crystal size of Merwinite. As the crystal size was smaller than $1 \mu \mathrm{m}$, the concentration of $\mathrm{Mg}$ around the Merwinite crystal was difficult to clarify by EDS analysis. The crystal phases were also Gehlenite and Merwinite by XRD.

In the case of slower cooling rate of $0.35^{\circ} \mathrm{C} / \mathrm{s}$, the crystal precipitated in the sample was larger and was from 5 to $7 \mu \mathrm{m}$, which was Merwinite. Although the matrix was the Gehlenite and Merwinite, there was some smaller structure could be seen. However, it could not clarify the composition distribution by EDS analysis.

The CCT diagram obtained by in situ observation might change by the precise XRD analysis from the reason mention above. Also the line of the beginning of the crystallization of CCT was lower than that obtained by calculation (Eq. $\left.(4)^{1)}\right)$. The precise investigation on the CCT diagram is now carrying out by the authors. The result will be published in the present Journal.

$$
\sum_{n=1}^{n} \frac{\Delta t_{i}}{Z_{i}}=1
$$

\section{Conclusion}

Using SHTT (Single Hot Thermocouple Technique), TTT and CCT diagrams of BF slags were measured. Crystallization behavior in the TTT and CCT diagrams of BF slag were clarified by XRD analysis, SEM observation and EDS analysis.

(1) The melting point of BF slags used in the present study were about $1400^{\circ} \mathrm{C}$.

(2) Crystal phases in the TTT diagram for BF slag were Gehlenite $\left(2 \mathrm{CaO} \cdot \mathrm{Al}_{2} \mathrm{O}_{3} \cdot \mathrm{SiO}_{2}\right)$ and Merwinite $\left(3 \mathrm{CaO} \cdot \mathrm{MgO} \cdot 2 \mathrm{SiO}_{2}\right)$.

(3) Merwinite precipitated faster than Gehlenite. The nose position of Merwinite in the obtained TTT diagrams was $4 \mathrm{~s}$ at $1090^{\circ} \mathrm{C}$. The nose of Gehlenite was $8 \mathrm{~s}$ at $1230^{\circ} \mathrm{C}$.

(4) CCT diagram had wider glass region than TTT diagram and the temperature of crystal region decreased to $1340^{\circ} \mathrm{C}$ at $1000 \mathrm{~s}$ and $1160^{\circ} \mathrm{C}$ at $14 \mathrm{~s}$.

\section{Acknowledgement}

The present study has been carried out by the support of the ISIJ Research Promotion Grant from 2004 to 2005. A part of this project has been performed by the support of JFE 21st Century Foundation in 2003. The authors would like to express a deep appreciation to the JFE 21st Century Foundation and the Iron and Steel Institution of Japan (ISIJ).

\section{REFERENCES}

1) Tekko Zairyo, Japan Institute of Metals, Sendai, (2002), 29.

2) NKK Tech. Rep., No. 177 (2002.6).

3) T. Akiyama and T. Mizuochi: Kankyo Kagaku Kaishi, 14 (2001), 143.

4) Report of Nippon Slag Association, Blast Furnace Slag for Cement, H15, (2003).

5) R. Eriksson and S. Seetharaman: Metall. Mater. Trans. B, 35B (2004), 461.

6) Y. Kashiwaya, C. E. Cicutti and A. W. Cramb: ISIJ Int., 38 (1998), 357.

7) Y. Kashiwaya, C. E. Cicutti, A. W. Cramb and K. Ishii: ISIJ Int., 38 (1998), 348.

8) Y. Kashiwaya and K. Ishii: ISIJ Int., 42 (2002), 71.

9) C. Orring, Y. Fang, N. Phinichka, S. Sridhar and A. W. Cramb: JOM$e, 51$ (1999), July.

10) P. Rocabois, J. N. Pontoire, J. Lehmann and H. Gaye; J. Non-Cryst. Solids, 282 (2001), 98.

11) M. Kowalski: Slag-Atlas, 2nd ed., Verlag Stahleisen GmbH, Duüsseldorf, (1995), 99.

12) J. H. Park, D. J. Min and H. S. Song: Metall. Mater. Trans. B, 35B (2004), 269

13) P. Rocabios, J. N. Pontoire, J. Lehmann and H. Gaye: J. Non-Cryst. Solids, 282 (2001), 98.

14) I. Barin: Thermochemical Data of Pure Substance, VCH, New York, (1989).

15) H. Nagasawa, T. Suzuki, M. Ito and M. Morioka: Phys. Chem. Miner, 28 (2001), 706.

16) M. Ito, H. Yurimoto, M. Morioka and H. Nagasawa: Lunar Planet. Sci., 32 (2001), 1518.pdf

17) H. Nagasawa, T. Suzuki, M. Ito and M. Morioka: Lunar Planet. Sci., 30 (1999), 1530.pdf.

\section{Appendix.}

Gibbs free energy of formation of Merwinite, Gehlenite and Akermanite were calculated by the data of Barin ${ }^{14)}$ and shown in Fig. A1. It is found that the free energy of Merwinite is lowest among three compounds and the order of the stability is Merwinite, Gehlenite and Akermanite.

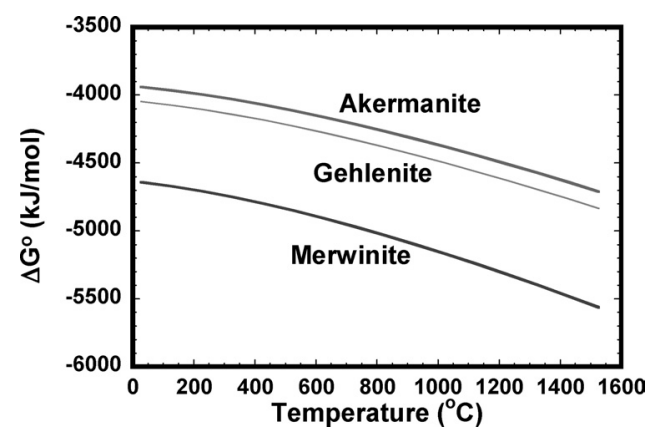

Fig. A1. Gibbs free energy of formation of Merwinite, Gehlenite and Akermanite. ${ }^{14)}$ 